\title{
DECENTRALIZATION AND INTERNATIONAL TAX COMPETITION
}

\author{
ECKHARD JANEBA \\ JOHN DOUGLAS WILSON
}

CESIFO WORKING PAPER NO. 854

CATEgory 1: Public FinANCE

FEBRUARY 2003

An electronic version of the paper may be downloaded

- from the SSRN website: www.SSRN.com

- from the CESifo website: www.CESifo.de 


\title{
DECENTRALIZATION AND INTERNATIONAL TAX COMPETITION
}

\begin{abstract}
This paper models tax competition between two countries that are divided into regions. In the first stage of the game, the strategy variable for each country is the division of the provision of a continuum of public goods between the central and regional governments. In the second stage, the central and regional governments choose their tax rates on capital. A country's decentralization level serves as a strategic tool through its influence on the mix of horizontal and vertical externalities that exist under tax competition. In contrast to standard tax competition models, decentralizing the provision of public goods may be welfare-enhancing.

JEL Code: F21, H2, H4.
\end{abstract}

\author{
Eckhard Janeba \\ Department of Economics \\ University of Colorado \\ Boulder, Colorado 80309-0256 \\ U.S.A. \\ Eckhard.Janeba@Colorado.EDU
}

\author{
John Douglas Wilson \\ Department of Economics \\ Marshall Hall \\ Michigan State University \\ East Lansing, MI 48824 \\ U.S.A. \\ Wilsonjd@msu.edu
}

Helpful comments and suggestions have been provided by participants in conferences at Queen's University, CORE, and the Economic and Social Research Institute in Tokyo; and at the Midwest International Economics Meeting. 


\section{Introduction}

The roles of central and lower-level governments in a federal system are imperfectly understood. Much of the local public economics literature treats these roles as exogenous. The different levels of government are each given control of various tax and expenditure instruments, and the central government can employ various policies to influence the behavior of lower-level governments. A few distinct approaches exist here. According to Tiebout (1956), the ability of mobile households to "vote with their feet" leads to the efficient provision of public goods by local governments. Builders of Tiebout models typically justify the involvement of local governments in public good provision by appealing to the difficulties a central government would encounter in inducing individuals to reveal their preferences for public goods. But only recently have researchers focused on formal models of informational asymmetries in a federal system. ${ }^{1}$ A weakness of this literature is that these asymmetries are assumed, rather than derived.

It is now well-understood that the behavior of independent governments is unlikely to be optimal in any reasonable sense, and a central government is needed to correct the various externalities and income distribution problems that arise in a system of independent governments. There exists a particularly large literature on tax competition, under which governments compete for scarce capital, leading to inefficiently low levels of taxation and public good provision. ${ }^{2}$ In contrast to Tiebout models, this literature emphasizes problems with the decentralized provision of public goods by independent governments. However, it seems to stack the deck in favor of centralized provision, because it typically assumes away any inefficiencies at the central level. ${ }^{3}$

A more recent literature tries to come to grips with the inefficiencies that would exist under central provision of public goods. In Oates (1972), these inefficiencies consist of uniform provision of public goods across different jurisdictions, which must be traded off against of the interjurisdictional externalities that might occur in a decentralized system (e.g., spillovers from public good provision). In contrast, Besley

\footnotetext{
${ }^{1}$ See, for example, Raff and Wilson (1997) and Lockwood (1999), and the references therein.

${ }^{2}$ See Wilson (1999) for a review.

${ }^{3}$ An exception is Wilson (2000).
} 
and Coate (2000) examine a model in which the behavior of the legislative system under centralization leads to an unequal (and inefficient) division of public-good expenditures across localities. Panizza (1999) examines a model in which the provision of a single public good is subject to greater spatial decay at the central level, and the amount of decentralization is determined at the central level by balancing the preferences of the median voter with central-government preferences for greater government size. ${ }^{4}$ The political-economy approach to fiscal federalism remains relatively unexplored.

Using a different approach, the current paper derives an active role for lower-level governments in public good provision. We consider a world economy in which the central governments of two countries provide public goods financed by taxes on mobile capital. Competition for this mobile capital leads to inefficiently low taxes and public good levels, as in the standard tax competition model (e.g., Wilson (1986) and Zodrow and Mieszkowski (1986)). Unlike the standard model, however, there exists a continuum of public goods and, therefore, the possibility for the central governments to decentralize the provision of some, but not all, public goods. From a single country's viewpoint, both horizontal and vertical externalities are involved in the provision of public goods by “regional” governments (e.g., state, local, or provincial). When a single regional government lowers its tax rate, it not only attracts capital away from other regions (the horizontal externality), but also expands the central government's tax base by attracting additional capital into the country (the vertical externality). As a result, regional governments may under- or over-provide public goods, depending on the relative sizes of these two externalities. We demonstrate that the central government can control these relative sizes by manipulating the division of public-good provision between the two levels of government. In so doing, it can influence the degree to which the country as a whole competes with the other country for scarce capital. In other words, decentralization emerges endogenously as a tool for gaining a strategic advantage over a rival country in a tax competition game. We also show that the uncoordinated decisions to decentralize by the two competing countries can be welfare-improving for both of

\footnotetext{
4 See also Arzaghi and Henderson (2002), which builds on this framework.
} 
them. In contrast to standard tax competition models, the decentralized provision of public goods can therefore play a welfare-enhancing role

The next section of this paper describes the model, and Section 3 investigates the optimal decentralization policies for a country. Section 4 examines the welfare implications of decentralization for the two countries, and Section 5 concludes.

\section{The Model}

Following the standard Zodrow-Mieszkowski model, consider a country consisting of a system of $\mathrm{N}>1$ identical regions, each containing a representative resident who supplies labor to competitive firms within the region. These firms use a constant-returns technology to produce output from this labor and mobile capital. This output is then sold to individuals as a final consumption good, and purchased by the region's government as the sole input in the production of public goods. There is a continuum of public goods, some of which may be produced by the central government, again using private output as the sole input. Specifically, an individual's utility function takes the form,

$$
\mathrm{u}=\mathrm{u}(\mathrm{x}, \mathrm{G}) ; \quad \mathrm{G}=\int_{0}^{1} g(n)^{\alpha} d n
$$

where $\mathrm{x}$ is private consumption, $\mathrm{G}$ is "aggregate" public good consumption, and $\mathrm{g}(\mathrm{n})$ is consumption of public good $\mathrm{n}$, with $0<\mathrm{n}<1$. We assume that $\mathrm{x}$ and $\mathrm{G}$ enter the utility function as normal goods, and that $\alpha<1$, indicating imperfect substitutability between the different public goods. We shall denote by $\mathrm{n} *$ the cutoff between goods supplied by regional governments and the central government, so that $\mathrm{g}(\mathrm{n})$ is supplied by regional governments if $\mathrm{n}<\mathrm{n}^{*}$. With public goods entering the model in a symmetric way, each level of government sets $\mathrm{g}(\mathrm{n})$ equal to a common value for all $\mathrm{n}$ under its control, $\mathrm{g}_{\mathrm{r}}$ for regional governments $\left(n<n^{*}\right)$ and $g_{c}$ for the central government $\left(n>n^{*}\right)$.

All residents possess the same endowments of labor and capital, $\mathrm{L}^{*}$ and $\mathrm{K}^{*}$. Thus, a resident's budget constraint is $\mathrm{x}=\mathrm{rK}^{*}+\mathrm{wL}^{*}$, where $\mathrm{r}$ is the after-tax return on capital and $\mathrm{w}$ is the wage rate. The before-tax return on capital in a given region is $\mathrm{r}+\mathrm{t}+$ 
$\mathrm{T}$, where $\mathrm{t}$ and $\mathrm{T}$ denote the tax rates levied on capital by the regional and the central government. (In equilibrium, all regions choose the same t.) There are no other taxes, implying that the government budget constraint for a given region is

$$
\mathrm{n}^{*} \mathrm{~g}_{\mathrm{r}}=\mathrm{tK}(\mathrm{r}+\mathrm{t}+\mathrm{T}),
$$

where $\mathrm{K}(\cdot)$ denotes the capital demanded by the region's firms as a function of the beforetax return on capital (also called the "cost of capital"). In contrast, the central government's budget constraint is

$$
\left(1-n^{*}\right) g_{c}=T K(r+t+T),
$$

stated in terms of expenditures and tax revenue per region. We assume here that the public good is a publicly-provided private good in the sense that there is a constant marginal cost of providing it to another resident. Hence, there are no scale-economy arguments for centralizing the provision of the public good.

Assume now that there exist two identical countries, home and foreign, with the attributes just described, and that capital is mobile between them. We shall consider a symmetric Nash equilibrium in tax rates. The players in this game are both the regional and central governments. But before competition in tax rates occurs, the two central governments play a Nash game in decentralization policies, consisting of a choice of $\mathrm{n}^{*}$. The objective of both central and regional governments is welfare maximization, but regional governments care only about the welfare of their own residents, whereas each central government desires to maximize common utility obtained by all residents in the country. A subgame perfect equilibrium is investigated, with the countries correctly anticipating how their initial choices of $n^{*}$ affect the equilibrium taxes in the next stage of the game.

Given the fixed world supply of capital, the equilibrium $r$ is determined by the vector of "combined tax rates" for all of the regions, $t+T$ for a region with tax $t$ in a country with central tax T. Let $\mathrm{dr} / \mathrm{dt}$ denote the marginal impact of a single region's $\mathrm{t}$ on $\mathrm{r}$, and define dr/dT similarly for a single country's $\mathrm{T}$. Both of these derivatives are 
negative, since a higher cost of capital lowers the demand for capital (i.e., $\mathrm{K}^{\prime}<0$ ). International capital mobility implies that a rise in $\mathrm{T}$ is not fully capitalized into r, i.e., $\mathrm{dr} / \mathrm{dT}<1$. Since a rise in T increases the cost of capital in all of a country's regions, it clearly has a greater impact on $r$ than a rise in a single region's tax rate. In particular, the symmetry between regions implies

$$
0<-\frac{d r}{d t}=-\frac{1}{N} \frac{d r}{d T}<\frac{1}{N}
$$

Consider now the rules for equilibrium public good provision that governments follow in the second stage of the game, after $n^{*}$ has been chosen. Appendix A shows that each regional government chooses its t to satisfy

$$
\frac{u_{G}}{u_{x}} \alpha g_{r}^{\alpha-1}=\frac{1+\left(1-\frac{K^{*}}{K}\right) \frac{d r}{d t}}{1-\tau \varepsilon\left(1+\frac{d r}{d t}\right)-\beta \varepsilon\left(\frac{1}{N}+\frac{d r}{d t}\right)\left(\frac{g_{r}}{g_{c}}\right)^{1-\alpha}},
$$

where $\varepsilon$ is the demand elasticity for capital with respect to the before-tax return (measured positively), $\tau=\mathrm{t} /(\mathrm{r}+\mathrm{t}+\mathrm{T})$, and $\beta=\mathrm{T} /(\mathrm{r}+\mathrm{t}+\mathrm{T})$. Notice that positive values of $\tau$ and $\beta$ both contribute towards raising the marginal cost of public good provision above one (which is the marginal resource cost in this model). This rule generalizes the standard rule found in the tax competition literature (see Zodrow and Mieszkowski (1986)). The standard rule contains the term involving $\tau$ in the numerator, reflecting the cost associated with the capital outflow that occurs when the region raises its tax rate. This term represents a horizontal externality, since other regions obtain more capital when one region raises its tax rate (although the capital supply for the nation as a whole declines). The term involving $\beta$ reflects the vertical relation between the regional and central governments. The use of tax rates as strategy variables implies that each regional government is treating its central government's tax rate as fixed, while fully recognizing the impact of its own tax rate on the central government's supplies of public 
goods. In particular, the rise in a single region's t lowers the central government's tax base, and the region's share of the resulting decline in public-good expenditures is $1 / \mathrm{N}$. Since the remaining share, $(\mathrm{N}-1) / \mathrm{N}$, is born by other regions, it represents the vertical externality. Finally, the term involving $\mathrm{dr} / \mathrm{dt}$ in the numerator allows for terms-of-trade effects associated with imports or exports of capital. This term will vanish in the symmetric equilibria that we consider, since no country will import or export capital.

Now the central government satisfies a similar condition, except that $\mathrm{dr} / \mathrm{dT}$ obviously replaces $\mathrm{dr} / \mathrm{dt}$, and also the central government fully internalizes the vertical externality associated with the impact of a tax change on the regional tax bases (since it cares about the welfare of the residents in all regions). From Appendix A, this condition is

$$
\frac{u_{G}}{u_{x}} \alpha g_{c}^{\alpha-1}=\frac{1+\left(1-\frac{K^{*}}{K}\right) \frac{d r}{d T}}{1-\left(\tau\left(\frac{g_{c}}{g_{r}}\right)^{1-\alpha}+\beta\right) \varepsilon\left(1+\frac{d r}{d T}\right)},
$$

The marginal cost of public good provision, given by the right side, still contains tax terms, but only because a rise in T lowers the country's total stock of capital.

Condition (6) defines a relation between $g_{c}$ and $g_{r}$, which is depicted by curve CC in Figure 1. At sufficiently high levels of $g_{r}$, the marginal cost becomes prohibitively high, reducing $\mathrm{g}_{\mathrm{c}}$ to zero. Thus, the curve is generally downward sloping, although we cannot rule out upward sloping-segments without further restrictions.

To find where on $\mathrm{CC}$ the economy operates under a given level of decentralization ( $\left.\mathrm{n}^{*}\right)$, let us divide both sides of (5) by both sides of (6) and rearrange to obtain a necessary condition for both levels of government to be in equilibrium:

$$
1-\left(\frac{g_{c}}{g_{r}}\right)^{1-\alpha}=\varepsilon\left(1-\frac{1}{N}\right)\left(\beta\left(1+\frac{d r}{d T}\right)+\tau \frac{d r}{d T}\left(\frac{g_{c}}{g_{r}}\right)^{1-\alpha}\right)
$$


By substituting from the government budget constraints to express the tax rates in terms of the public good levels, we may rewrite (7) as follows:

$$
1-\left(\frac{g_{c}}{g_{r}}\right)^{1-\alpha}=g_{c} \frac{-K^{\prime}}{K^{2}}\left(1-\frac{1}{N}\right)\left(\left(1-n^{*}\right)\left(1+\frac{d r}{d T}\right)+n^{*} \frac{d r}{d T}\left(\frac{g_{r}}{g_{c}}\right)^{\alpha}\right) .
$$

This condition is illustrated by curve DD in Figure 1. As $\mathrm{g}_{\mathrm{r}}$ goes to zero, the left side of (8) goes to minus infinity unless $g_{c}$ goes to zero. For this reason, the DD curve lies below the CC curve at low levels of $g_{r}$. Note also that at high levels of $g_{r}, g_{c}$ must also be high. Otherwise the right side of (8) will be highly negative, whereas the left side is positive. For these reasons, we have drawn DD as an upward sloping curve that eventually rises above the $\mathrm{CC}$ curve, although once again we cannot rule out downwardsloping segments without further restrictions. Intuitively, $\mathrm{g}_{\mathrm{r}}$ and $\mathrm{g}_{\mathrm{c}}$ must generally move in the same direction to insure that each level of government faces the same marginal cost of raising $\mathrm{G}$ one unit (which it equates to the marginal benefit, $\mathrm{u}_{\mathrm{G}} / \mathrm{u}_{\mathrm{x}}$ ).

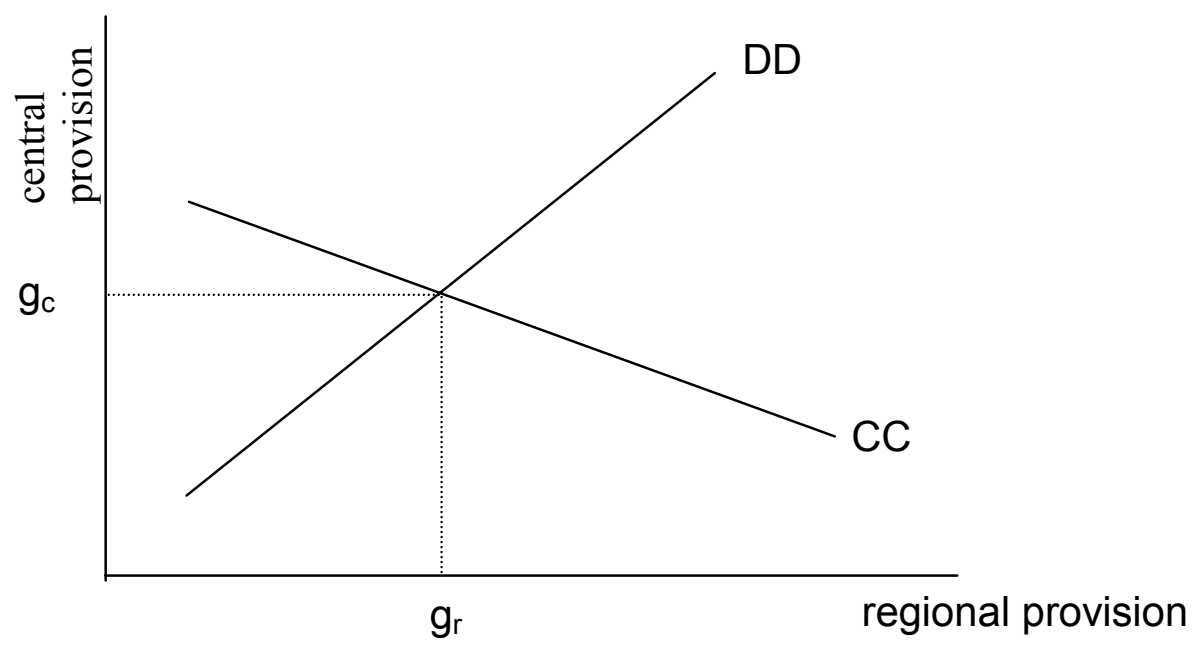

Figure 1 
The equilibrium for the country is represented by the point where these two curves cross. For second-best problems of this type, we cannot rule out multiple crossings or even no crossing, due to discontinuities in the CC or DD curves (which might occur if $\mathrm{dr} / \mathrm{dT}$ is highly sensitive to the level of taxation). Our strategy will be to examine the properties of any symmetric equilibrium for the two countries that does exist. We do assume that a country's equilibrium $g_{r}$ and $g_{c}$ vary continuously with its level of decentralization, measured by $n^{*}$, and that the slopes of the reaction curves in tax space satisfy the normal condition for stability where they cross, as depicted in Figure 2 for the case of upward-sloping reaction curves. ${ }^{5} \quad$ Appendix B demonstrates that reaction curves can slope up or down, and so we consider both cases. ${ }^{6}$

\section{Equilibrium Decentralization}

This section demonstrates that both countries have some positive level of decentralization in any symmetric equilibrium (i.e., $\mathrm{n}^{*}>0$ ). The proof is by contradiction. We show that if both countries were centralized and setting their tax rates at their Nash values, given centralization, then each country would have an incentive to unilaterally decentralize the production of at least some public goods. In other words, decentralization is always the best response to the "centralization strategy." It follows that the only symmetric equilibrium is where both countries decentralize, at least partially. We also rule out asymmetric equilibria where one country decentralizes and the other remains fully centralized. Throughout the discussion, the policies for home are analyzed, since foreign behaves similarly.

A central preliminary result is that there exists some level of decentralization under which home behaves exactly as it would with full centralization. In particular, the central and regional governments all choose the same values for the $g(n)$ 's under their control, and this common value is the one that would be chosen under full centralization.

\footnotetext{
${ }^{5}$ For Figure 2, this means that the slope of each reaction curve is less than one where they cross. The continuity assumption holds in the case of where the relation between a country's output and capital usage is represented by a quadratic production function, since then the derivatives $\mathrm{dr} / \mathrm{dT}$ and $\mathrm{K}$ ' are constant.

${ }^{6}$ To avoid unnecessary complications, we assume throughout the paper that the sign of this slope does not change over the relevant range of tax rates. In the knife-edge case of a horizontal reaction curve for home (vertical for foreign), the strategic considerations discussed in this paper would disappear.
} 
As a result, the combined unit tax rate, $\mathrm{t}+\mathrm{T}$, is identical to the $\mathrm{T}$ chosen under full centralization.

Before turning to the formal proof of this claim, we first explain it intuitively. As described above, there are two externalities here from home's viewpoint. First, there is the usual fiscal externality from horizontal tax competition, which tends to create too little provision of public goods (and, correspondingly, lower taxes than the central government would choose). Second, there is the vertical externality. When one region increases its tax rate, the total amount of capital supplied to home declines, causing a drop in the central government's tax revenue. As a result, the central government must reduce its public good supplies, which harms all regions. This consideration tends to create too much public good provision at the regional level.

Thus, the vertical and horizontal externalities have opposite signs. However, when only a small fraction of the public goods are decentralized, the vertical externality dominates. The reason is that the magnitude of each externality depends on the level of taxation at each level of government. With regional governments providing few public goods, regional taxes are small relative to central taxes. Hence, the horizontal externality is small relative to the vertical externality, implying overprovision of the public good. On the other hand, when regional governments provide most of the public goods, the horizontal externality dominates. Thus, there exists some intermediate value of $n^{*}$ under which there is neither overprovision nor underprovision. In other words, regional governments choose the same public good levels that are chosen in the fully centralized economy.

This result is now stated and proved as a lemma:

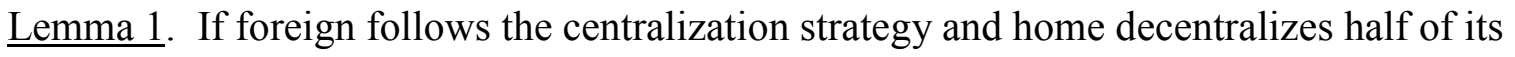
pubic goods $\left(n^{*}=1 / 2\right)$, then home's regional and central governments both set $g(n)$ equal to the common $\mathrm{g}(\mathrm{n})$ that would prevail under full centralization.

Proof. If home is fully centralized $\left(\mathrm{n}^{*}=0\right)$, then it chooses the same tax rate as foreign in the symmetric Nash equilibrium. This tax rate satisfies the central government's optimality condition, given by (6), with the regional tax rate, $\tau$, set equal to zero (and 
with $\mathrm{K}=\mathrm{K}^{*}$ in the numerator, since the two countries have the same tax rates). To construct a (partially) decentralized equilibrium that replicates this centralized equilibrium, we move some public goods to the regional level $\left(n^{*}>0\right)$ but keep their levels unchanged. In this case, the combined tax rate is unchanged, and (6) continues to hold.

For this level of public good provision to be in equilibrium, $\mathrm{n}^{*}$ must be set where it also satisfies the regional governments' optimality condition, given by (5). In other words, the $g_{r}$ in (5) must also satisfy (6), implying that regional governments are following the same rules used by the central government and therefore choosing the same g. The intuitive argument provided before the lemma claimed that this $n^{*}$ exists where the regional governments have reached a size at which the horizontal and vertical externalities offset each other. In fact, condition (8) confirms this argument. If home and foreign choose identical combined tax rates, then they possess identical capital supplies, and we can solve for $\mathrm{dr} / \mathrm{dT}=-1 / 2{ }^{7}$ In this case, both sides of (8) equal zero when $\mathrm{n}^{*}=1 / 2$ and $\mathrm{g}_{\mathrm{c}}=\mathrm{g}_{\mathrm{r}}$. This completes the proof. Q.E.D.

It is interesting to note that the $\mathrm{n}^{*}$ identified in Lemma 1 would rise if we increased the number of countries. For J countries, we would have, $\mathrm{dr} / \mathrm{dT}=-1 / \mathrm{J}$, and the level of $n^{*}$ at would both sides of (8) equaled zero would then be $n^{*}=1-(1 / J)$, which rises with $\mathrm{J}$. This result may be easily explained. With more countries, the importance of the horizontal externality declines relative to the vertical externality, because a rise in one region's tax rate provides other regions in the same country with less capital; more of this capital escapes to the other country. Thus, $\mathrm{n}^{*}$ must be higher for the horizontal and vertical externalities to offset each other.

Now consider marginal changes in home's $n^{*}$ from $n^{*}=1 / 2$. These changes will generally distort the behavior of regional governments, causing their public good choices to differ from those of the central government. However, the optimality of public good levels under the initial $n *$ implies that this distortion is second-order, holding fixed the

\footnotetext{
${ }^{7}$ In equilibrium, the difference in the two countries' combined tax rates equals the difference in their marginal products of capital. Letting $f(K)$ denote the production function, this marginal product is $\mathrm{f}^{\prime}\left(\mathrm{K}_{\mathrm{i}}\right)$ for country $i(i=H, F)$. Thus, we can solve for home's $d r / d T$ to obtain $d r / d T=-f^{\prime}\left(K_{F}\right) /\left[f^{\prime}\left(K_{H}\right)+f^{\prime}\left(K_{F}\right)\right]$, which equals $1 / 2$ in the symmetric equilibrium.
} 
tax chosen by the foreign government. But the foreign tax does change, because it responds to the change in home's combined tax rate. We first investigate how the change in $\mathrm{n}^{*}$ affects home's combined tax rate.

Lemma 2. Starting from the $n^{*}=1 / 2$ for home, and holding fixed foreign's tax rate at its full-centralization value, a marginal reduction in $n^{*}$ causes home's equilibrium combined tax rate to rise.

Proof. Return to the Figure 1, which depicts the equilibrium for $n^{*}=1 / 2$ as the intersection of the DD and CC curves. A crucial property of the latter curve is that a small move down the $\mathrm{CC}$ curve from this equilibrium must increase the combined tax rate. To see this, suppose instead that $g_{c}$ falls enough as $g_{r}$ rises to keep the combined tax rate unchanged (implying no change in the elasticity $\varepsilon$ or $\mathrm{dr} / \mathrm{dT}$ ). With $\tau+\beta$ staying fixed, it is clear that $\tau\left(\mathrm{g}_{\mathrm{c}} / \mathrm{g}_{\mathrm{r}}\right)^{1-\alpha}+\beta$ falls, lowering the right side of (6). On the other hand, $\mathrm{G}$ and $\mathrm{x}$ are unchanged (to a first-order approximation), since total public good expenditures have not changed and the initial equality between $g_{c}$ and $g_{r}$ implies equal marginal utilities. Thus, the left side of (6) rises, due to the fall in $\mathrm{g}_{\mathrm{c}}$. By the secondorder conditions for $\mathrm{g}_{\mathrm{c}}$, a higher $\mathrm{g}_{\mathrm{c}}$ is needed to satisfy (6). It follows that tax revenue increases.

Now suppose that $n^{*}$ falls below $1 / 2$. Holding $g_{r}$ and $g_{c}$ fixed at their common value under the initial $n^{*}$, there is no change in total expenditures on the public goods and, hence, the combined tax rate. Thus, condition (6) is undisturbed, implying that the CC curve continues to intersect the original DD curve at the same point (although its shape elsewhere may change). However, the fall in $n^{*}$ raises the right side of (8) above zero, and equilibrium is restored with $\mathrm{g}_{\mathrm{c}} / \mathrm{g}_{\mathrm{r}}$ falling to make the left side positive too. Thus, the fall in $\mathrm{n}^{*}$ moves the economy down the CC curve, which can be represented in Figure 1 as a shift in the DD curve to the right. It follows that the fall in $n^{*}$ raises home's combined tax rate. Q.E.D. 
We have basically shown that a reduction in home's $n^{*}$ raises its reaction curve, relating its combined tax rate to the tax rate chosen by foreign. In Figure 2, this shift is illustrated by reaction curves $\mathrm{HH}$ and H'H'. This result can be understood by again appealing to comparison of horizontal and vertical externalities. At $n^{*}=1 / 2$, these two externalities are exactly offsetting each other. But lowering $n *$ transfers expenditures to the central government, thereby increasing the importance of vertical externality relative to horizontal externality. Since the vertical externality leads to "overprovision" of public goods, it is not surprising to learn that $\tau+\beta$ rises.

Reversing the above arguments shows that a rise in $\mathrm{n}^{*}$ lowers home's reaction curve. Thus decentralization becomes desirable because it provides a method by which home can manipulate its reaction curve, thereby achieving a strategic advantage over foreign. ${ }^{8}$

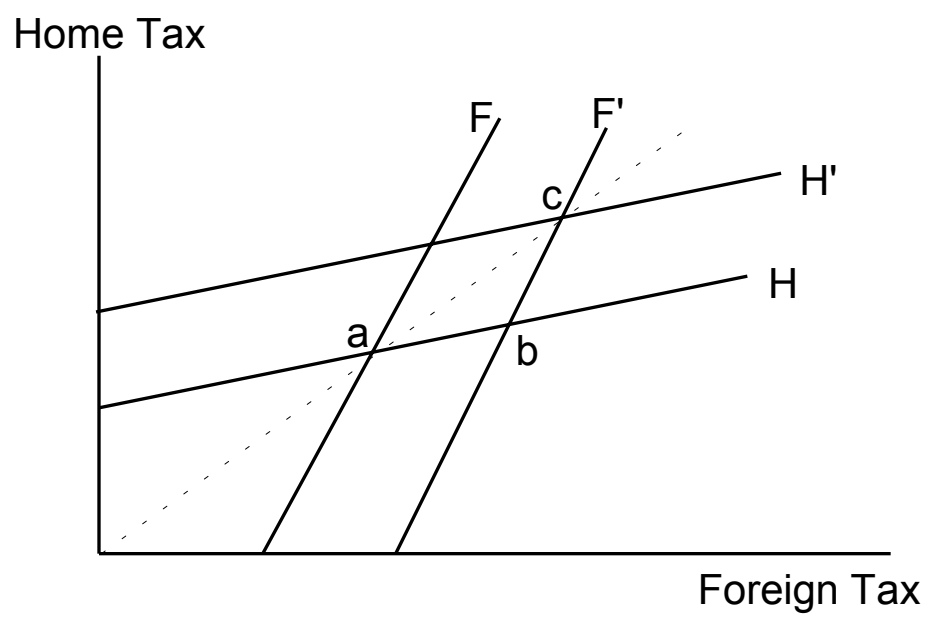

Figure 2

Exactly how $n^{*}$ should be set to achieve this desirable effect depends on the slopes of the reaction curves. If reaction curves slope up, as often assumed, then home should undertake a decentralization strategy that raises its reaction curve. Doing so induces foreign to raise its taxation of capital, and home benefits from this change 
through the resulting inflow of capital (induced by reduction in the equilibrium $r$ ). ${ }^{9}$ If reaction curves slope down, then home has an incentive to lower its reaction curve, since foreign's equilibrium tax rate now rises. In neither case, however, is it desirable for home to choose full centralization, given that foreign is pursuing the full-centralization strategy. We have seen that the taxes and public good levels chosen under full centralization correspond to those chosen under a decentralization strategy with $n^{*}=1 / 2$. By Lemma 2, home can shift its reaction curve up or down by altering $n *$ from this value, and for a small enough change, any resulting inefficiencies in public good provision are second-order in importance. A symmetric argument applies to foreign. We conclude:

Proposition 1. In any symmetric equilibrium, both countries choose some level of decentralization.

The next proposition identifies a case where decentralization is necessarily partial:

Proposition 2. If reaction curves slope up, then decentralization is necessarily partial in a symmetric equilibrium: some public goods are produced by the central government and others are produced by the regional governments.

Proof. Suppose instead that $n^{*}=1$ in both countries. In this case, there is only a horizontal externality. If we then reduce home's $n^{*}$ to zero, this externality will be eliminated, and public good provision will rise (compare (5) and (6)). Holding foreign's tax rate fixed, home's welfare necessarily increases, since the central government's objective is to maximize welfare, summed across regions. In addition, the higher tax rate imposed by home implies an upward shift in home's reaction curve. As we previously noted, this change is also beneficial to home, since it leads to a higher tax rate for foreign.

\footnotetext{
${ }^{8}$ Although Lemma 2 is a local result, concerning how a small change in $\mathrm{n}^{*}$ affects home's reaction curve in a small neighborhood of the initial equilibrium, the subsequent propositions do not require stronger global comparisons.

${ }^{9}$ A capital inflow benefits home because the tax on capital raises the marginal product of capital above the opportunity cost of capital. Since home country becomes a capital importer, the drop in $r$ also represents a beneficial terms-of-trade effect.
} 
Thus, the move to full centralization raises welfare, which contradicts the optimality of $\mathrm{n}^{*}=1$. Q.E.D.

Thus, a central conclusion is that each country will often desire to produce public goods at both levels of government. For the case of downward-sloping reaction curves, however, we cannot rule out the possibility that the central governments vanish as public good providers.

The standard Zodrow-Mieszkowski model can exhibit multiple equilibria, including asymmetric equilibria, where identical regions choose different tax policies. To focus on the decentralization issue, however, let us assume that reaction curves in tax space cross only once and ask whether the decision about whether to decentralize can be a separate source of asymmetry. We showed that one country would desire to decentralize if the other country is centralized. But is it possible for one country to desire to remain fully centralized, given that the other has decentralized? The answer is "no." To see this, suppose now that home decentralizes, conditional on foreign choosing a policy of full centralization. Would foreign desire to maintain this policy? Assume first that reaction curves slope up, and recall that home decentralizes in this case as a means of raising its reaction curve, thereby inducing foreign to raise its tax rate. As shown in Figure 2, this shift increases home's combined tax rate above foreign's tax rate. As the low-tax country, foreign is a net importer of capital. But then foreign can gain from decentralization for two reasons. Suppose that it sets $n^{*}=1 / 2$, which replicates the centralization policy. If it now reduces $n^{*}$, we have seen that its reaction curves shifts up. Hence, foreign experiences the same source of gains that led home to decentralize, i.e., it induces home to raise its combined tax rate, producing a beneficial capital flow from home to foreign. But there is also a second source of gains for foreign. Given its initial status as a capital importer, it gains from the resulting terms-of-trade effects. In particular, the rise in both countries' combined tax rates depresses the after-tax return on capital, which necessarily benefits a capital-importing country. Thus, foreign will choose to decentralize, given that home is decentralized. In other words, the only possible 
equilibrium involves decentralization by both countries. For the case where reaction curves slope down, a similar argument again implies decentralization by both countries.

\section{Welfare}

The welfare effects of decentralization depend on the slopes of the reaction curves in tax space. In the case where reaction curves slope down, however, it is clear that decentralization is welfare worsening. In this case, both countries are decentralizing in an effort to lower their reaction curves. But the result is that their combined tax rates both decline, without any change in the allocation of capital. Public goods are underprovided when the two countries are fully centralized, and so this decline in tax rates aggravates the underprovision problem. In addition, we have seen that decentralization results in an inefficient allocation of tax revenue between the two levels of government, with the chosen g(n)'s now differing. For both reasons, welfare is lower than it would be if both countries were centralized.

On the other hand, welfare rises in the case where reaction curves slope up. In this case, decentralization leads to a welfare-enhancing rise in tax rates, but again at the cost of inefficiencies in the relative supplies of different public goods. But these costs can never offset the gains from higher tax rates. To see this, we can decompose the move from centralization to decentralization into two steps. First shift up foreign's reaction curve, moving the equilibrium from point $a$ to point $b$ in Figure 1. Home benefits from the implied tax changes because it becomes the low-tax country and therefore experiences an inflow of capital. This inflow expands its tax base, thereby increasing its provision of public goods. In addition, there is a beneficial terms-of-trade effect for home associated with home's new status as a capital importer. Since both countries' taxes rise, the after-tax return on capital falls, thereby benefiting home in this role.

Having shifted up foreign's reaction curve, let home now implement the equilibrium level of decentralization, thereby also shifting up its reaction curve. The resulting change in tax rates is depicted by the move from point $\mathrm{b}$ to point $\mathrm{c}$ in Figure 1. By a standard revealed-preference argument, home clearly benefits from this change; 
otherwise, it would not implement it. Since the two countries are identical, a similar argument must show that decentralization also benefits foreign.

To conclude, decentralization serves a welfare-enhancing role in this model. It does so by offsetting the welfare losses from tax competition between the two countries. This competition leads to taxes and public good levels that are inefficiently low. By decentralizing in a way that creates relatively strong vertical externalities, the central governments induce their regional governments to increase their public good supplies above those that would be chosen by the central governments alone.

\section{Concluding Remarks}

In traditional models of fiscal federalism, an important role for the central government is correct the externalities created by the independent behavior of communities or regions. There is a large literature on the use of intergovernmental grants for this purpose, and various restrictions on the behavior of lower-level governments may also be used. However, central governments are not immune to political pressures that limit the usefulness of such instruments. Thus, it seems useful to explore ways of designing the structure of a federal system to reduce the harmful effects of externalities, without the need for an active central government role. In this paper, we have examined the division of public good provision between different levels of government as aspect of this design. Interestingly, this division works not so much by reducing the size of horizontal and vertical externalities, but rather by offsetting one against another until their net effect is optimal (but nonzero, given their use as a strategic device in this model). The analysis therefore departs quite dramatically from the firstbest analysis of externalities, which says that they should be targeted directly with the appropriate subsidies or taxes. Instead, it points to the value of analyzing different externalities together, rather than in isolation, and designing a federal system that optimally controls their net impact. For the particular externalities under consideration, horizontal and externality, we hope to have demonstrated the usefulness of departing from the common practice of treating their relative importance as exogenous.

Our stylized model may hold some lessons in the in the context of capital mobility within and across the U.S. and the European Union. Both countries have central and 
regional governments, and at the same time there is a fair amount of investment across the Atlantic. The results of our analysis provide new arguments in the debate over fiscal decentralization both in the EU and the U.S. In general, these debates typically ignore aspects of international capital mobility.

For example, in the EU most of the existing spending and taxing power rests with the national governments. ${ }^{10}$ Some people object to giving more fiscal power to the EU, perhaps out of fear that there would be too much waste due to a big bureaucracy. Others would like to see more coordination of tax policies in order to reduce the inefficiencies from horizontal tax competition among nation states. Our analysis suggests that allocating more fiscal authority to the EU level might improve the welfare of European citizens when competing with the U.S. for internationally mobile capital. ${ }^{11}$

Relative to the EU, spending power in the U.S. is much more evenly distributed between the federal government and the states. Yet it is interesting to note how expenditures are financed at each level. Although the importance of the corporation tax at the federal level has declined over the last few decades, corporate tax revenues play a more minor role in state budgets. Obviously our model cannot fully address this discrepancy because we do not allow for multiple tax instruments. Our analysis may suggest, however, the conjecture that individuals would be better off in the U.S. if more revenues were collected at the state level from the internationally mobile factor.

Acknowledgments. Helpful comments and suggestions have been provided by participants in conferences at Queen's University, CORE, and the Economic and Social Research Institute in Tokyo; and at the Midwest International Economics Meeting.

\footnotetext{
${ }^{10}$ The EU budget is about $1 \%$ of member countries' GDP, whereas national government spending at all levels is often in the range of $40-50 \%$ of national GDP.

${ }^{11}$ Here and below, we consider the case of upward-sloping reaction curves, in which case the analysis shows that the federal system should be designed to increase taxes on mobile capital.
} 


\section{Appendix A}

This appendix derives conditions (5) and (6) in the text. For (6), the central government solves the problem:

$$
\begin{aligned}
& \operatorname{Max} u\left(\mathrm{rK}^{*}+\mathrm{wL}^{*}, \mathrm{G}\right) \\
& \mathrm{T}, \mathrm{g}_{\mathrm{c}}, \mathrm{g}_{\mathrm{r}} \\
& \text { s.t. } \quad\left(1-\mathrm{n}^{*}\right) \mathrm{g}_{\mathrm{c}}=\mathrm{TK}(\mathrm{r}+\mathrm{t}+\mathrm{T}) ; \\
& \mathrm{n}^{*} \mathrm{~g}_{\mathrm{r}}=\mathrm{tK}(\mathrm{r}+\mathrm{t}+\mathrm{T}) ;
\end{aligned}
$$

where $\mathrm{G}$ is given by (1) and $\mathrm{w}$ is determined by $\mathrm{r}+\mathrm{t}+\mathrm{T}$ via a factor price frontier, denoted $\mathrm{w}(\mathrm{r}+\mathrm{t}+\mathrm{T})$. Given the assumption of Nash behavior, the central government treats $\mathrm{t}$ as fixed but recognizes that $\mathrm{g}_{\mathrm{r}}$ adjusts to satisfy the regional governments' budget constraints as T changes. Substituting the two budget constraints into the objective function and differentiating with respect to $\mathrm{T}$ gives the following first-order condition:

$$
u_{x}\left[\left(K^{*}+w^{\prime} L^{*}\right) \frac{d r}{d T}+w^{\prime} L^{*}\right]+u_{G}\left[\alpha g_{c}^{\alpha-1} K+\left[\alpha g_{c}^{\alpha-1} T+\alpha g_{r}^{\alpha-1} t\right] K^{\prime}\left[1+\frac{d r}{d T}\right]\right]=0
$$

For zero profits, we must have (using the envelope theorem), w' $=-\mathrm{K} / \mathrm{L}^{*}$. Substituting this expression into (A.3), dividing through by $\mathrm{u}_{\mathrm{x}} \mathrm{K}$, and rearranging gives,

$$
\frac{u_{G}}{u_{x}} \alpha g_{c}^{\alpha-1}\left[1-\left(t\left(\frac{g_{c}}{g_{r}}\right)^{1-\alpha}+T\right)\left(\frac{-K^{\prime}}{K}\right)\left(1+\frac{d r}{d T}\right)\right]=1+\left(1-\frac{K^{*}}{K}\right) \frac{d r}{d T}
$$

Noting that $-K^{\prime} R / K$ equals the elasticity $\varepsilon$, we may then rearrange (A.4) to get (6).

The problem for a single region is set up in a similar way, except that we must now distinguish between this region and the other regions in the country. Thus, the central government's budget constraint becomes, 


$$
\left(1-n^{*}\right) g_{c}=T\left[K(r+t+T)+(N-1) K\left(r+t^{o}+T\right)\right]
$$

where $\mathrm{t}$ is the tax rate for the region in question, and $\mathrm{t}^{\mathrm{o}}$ is the tax rate for all other regions. Each regional government receives 1/Nth of the expenditures provided by the central government. Hence, a change in $t$ alters each $g_{c}$ going to the given region by an amount equal to $\mathrm{TK}^{\prime}[1 / \mathrm{N}+\mathrm{dr} / \mathrm{dt}] /\left(1-\mathrm{n}^{*}\right)$. In contrast, the change in each $\mathrm{g}_{\mathrm{r}}$ for the region is once again $\mathrm{K}+\mathrm{tK} \mathrm{K}^{\prime}[1+\mathrm{dr} / \mathrm{dt}] / \mathrm{n}^{*}$. By differentiating the objective function given in (P.1) with respect to $t$ and using these two expressions, we obtain a first-order condition that differs from (A.3) in an understandable way:

$u_{x}\left[\left(K^{*}+w^{\prime} L^{*}\right) \frac{d r}{d t}+w^{\prime} L^{*}\right]+u_{G}\left[\alpha g_{r}^{\alpha-1} K+\alpha g_{r}^{\alpha-1} t K^{\prime}\left[1+\frac{d r}{d t}\right]+\alpha g_{c}^{\alpha-1} T K^{\prime}\left[\frac{1}{N}+\frac{d r}{d t}\right]\right]=0$

By once again using the equality, $w^{\prime}=-\mathrm{K} / \mathrm{L}^{*}$, we may transform (A.6) into (5) in the text. 


\section{$\underline{\text { Appendix B }}$}

This appendix provides examples of upward- and downward-sloping reaction curves, relating the home country's combined tax rate, $\mathrm{t}+\mathrm{T}$, to the foreign country's combined tax rate. ${ }^{12}$ First, we assume that the production function is quadratic: $f(K)=$ $\gamma \mathrm{K}-\eta \mathrm{K}^{2}$. With a quadratic production function, a country's demand curve for capital (relating the marginal product of capital to $\mathrm{K}$ ) is linear. In this case, $\mathrm{dr} / \mathrm{dT}$ is a constant, which simplifies matters considerably. Next we assume that the utility function takes the form

$$
\mathrm{u}=\mathrm{x}+\int_{0}^{1} \log g(n) d n
$$

which corresponds to the special case of (1) where $\alpha$ goes to zero.

To express the central government's optimality condition for this special case, substitute $\alpha=0$ into (6), and substitute - K'R/K for the elasticity $\varepsilon$ :

$$
\frac{1}{g_{c}}=\frac{1+\left(1-\frac{K^{*}}{K}\right) \frac{d r}{d T}}{1-\frac{T}{1-n^{*}} \frac{\left(-K^{\prime}\right)}{K}\left(1+\frac{d r}{d T}\right)},
$$

where use has been made of the equality, $\mathrm{g}_{\mathrm{c}} / \mathrm{g}_{\mathrm{r}}=\mathrm{Tn} * /\left(\mathrm{t}\left(1-\mathrm{n}^{*}\right)\right)$. Next multiply both sides of (B.2) by K times the denominator on the right side of (B.2), and substitute (1-n*)/T for $\mathrm{K} / \mathrm{g}_{\mathrm{c}}$ :

$$
\frac{1-n^{*}}{T}\left(1-\frac{T}{1-n^{*}} \frac{\left(-K^{\prime}\right)}{K}\left(1+\frac{d r}{d T}\right)\right)=K+\left(K-K^{*}\right) \frac{d r}{d T}
$$

Rearranging terms gives

\footnotetext{
12 Brueckner and Saavedra (2001) also construct examples of upward- and downward-sloping reaction curves, but they assume that preferences are linear, which violates the critical assumption in the current model that different public good levels are imperfect substitutes.
} 


$$
\frac{1-n^{*}}{T}=\left(K+\frac{\left(-K^{\prime}\right)}{K}\right)\left(1+\frac{d r}{d T}\right)-K * \frac{d r}{d T}
$$

Now a rise in foreign's combined tax rate shifts capital to home, represented by a rise in K. Thus, we may differentiate (B.4) with respect to $\mathrm{K}$ to show that $\mathrm{T}$ rises (falls) with foreign's tax rate if

$$
\frac{d\left(-K^{\prime} / K\right)}{d K}<(>)-1
$$

Thus, the critical consideration here is how the capital demand derivative $\mathrm{K}^{\prime}$ changes relative to capital demand as $K$ rises. Since $K^{\prime}$ is fixed, we know that $-K ' / K$ falls. For sufficiently elastic demand, however, the fall in $-\mathrm{K}^{\prime} / \mathrm{K}$ will be greater than one in absolute value, implying T rises with foreign's combined tax rate.

Consider finally how home's regional tax rate changes with foreign's combined tax rate. Once again using $\alpha=0$ and the condition, $\mathrm{g}_{\mathrm{r}} / \mathrm{g}_{\mathrm{c}}=\left(\mathrm{t}\left(1-\mathrm{n}^{*}\right)\right) /\left(\operatorname{Tn}^{*}\right)$, optimality condition (5) can be written:

$$
\frac{n^{*}}{t}=\frac{K+\left(K-K^{*}\right) \frac{d r}{d t}}{1-t\left(\left(1+\frac{d r}{d t}\right)+\left(\frac{1}{N}+\frac{d r}{d t}\right)\left(\frac{1-n^{*}}{n^{*}}\right)\right) \frac{\left(-K^{\prime}\right)}{K}}
$$

Manipulation gives a condition somewhat more complicated than (B.5):

$$
\frac{n^{*}}{t}=\left(K\left(1+\frac{d r}{d t}\right)+\left(1+\frac{d r}{d t}-\left(1-n^{*}\right)\left(1-\frac{1}{N}\right)\right) \frac{\left(-K^{\prime}\right)}{K}\right)-K^{*} \frac{d r}{d t}
$$

As before, a sufficiently large negative impact of $\mathrm{K}$ on $-\mathrm{K}^{\prime} / \mathrm{K}$ implies an upward-sloping reaction curve, but now the critical condition is: 


$$
\frac{d\left(-K^{\prime} / K\right)}{d K}<(>)-\frac{1+\frac{d r}{d t}}{1+\frac{d r}{d t}-\left(1-n^{*}\right)\left(1-\frac{1}{N}\right)}<-1
$$

where $\mathrm{dr} / \mathrm{dt}=-1 /(2 \mathrm{~N})$. The condition for $\mathrm{t}$ to rise with the foreign combined tax rate is somewhat more stringent than (B.5). As the number of regions goes to infinity, the ratio in (B.8) converges to $1 / \mathrm{n}^{*}$. 


\section{$\underline{\text { References }}$}

Arzaghi, Mahammad, and Vernon Henderson. (2002). "Why Countries are Fiscally Decentralizing?" Unpublished manuscript.

Besley, Timothy, and Stephen Coate. (2000) “Centralized versus Decentralized Provision of Local Public Goods: A Political Economy Analysis." Unpublished manuscript.

Brueckner, Jan K., and L.A. Saavedra. (2001). "Do Local Governments Engage in Strategic Property-Tax Competition?" National Tax Journal 54, 203-229.

Lockwood, Ben. (1999). “Inter-Regional Insurance.” Journal of Public Economics 72, 137.

Oates, Wallace. (1972). Fiscal Federalism. New York: Harcourt Brace.

Panizza, Ugo. (1999). "On the Determinants of Fiscal Centralization: Theory and evidence." Journal of Public Economics 74, 97-139.

Raff, Horst, and John Wilson. (1997). “Income Redistribution with Well-Informed Local Governments." International Tax and Public Finance 4, 407-427.

Tiebout, Charles M. (1956). “A Pure Theory of Local Expenditures.” Journal of Political Economy 64, 416-424.

Wilson, John. (1986). “A Theory of Interregional Tax Competition.” Journal of Urban Economics 19, 296-315.

Wilson, John. (1999). “Theories of Tax Competition.” National Tax Journal 52, 269-304. 
Wilson, John (2000). “Welfare-Improving Competition for Mobile Capital.” Unpublished manuscript.

Zodrow, George R., and Peter Mieszkowski. (1986). "Pigou, Tiebout, Property Taxation, and the Underprovision of Local Public Goods." Journal of Urban Economics 19, 356-370. 


\section{CESifo Working Paper Series}

(for full list see www.cesifo.de)

789 B. Gabriela Mundaca, Moral Hazard Effects of Bailing out under Asymmetric Information, October 2002

790 Gene M. Grossman and Edwin L.-C. Lai, International Protection of Intellectual Property, October 2002

791 John Hassler, José V. Rodriguez Mora, Kjetil Storesletten, and Fabrizio Zilibotti, A Positive Theory of Geographic Mobility and Social Insurance, October 2002

792 Paul De Grauwe and Marianna Grimaldi, The Exchange Rate in a Model with Heterogeneous Agents and Transactions Costs, October 2002

793 Guido Friebel and Mariassunta Giannetti, Fighting for Talent: Risk-shifting, Corporate Volatility, and Organizational Change, October 2002

794 Jan Erik Askildsen, Badi H. Baltagi, and Tor Helge Holmås, Will Increased Wages Reduce Shortage of Nurses? A Panel Data Analysis of Nurses' Labour Supply, October 2002

795 Marko Köthenbürger and Panu Poutvaara, Social Security Reform and Intergenerational Trade: Is there Scope for a Pareto-Improvement?, October 2002

796 Paul De Grauwe and Laura Rinaldi, A Model of the Card Payment System and the Interchange Fee, October 2002

797 Volker Böhm and Tomoo Kikuchi, Dynamics of Endogenous Business Cycles and Exchange Rate Volatility, October 2002

798 Mariam Camarero, Javier Ordóñez, and Cecilio Tamarit, The Euro-Dollar Exchange Rate: Is it Fundamental?, October 2002

799 Misa Tanaka, How Do Bank Capital and Capital Adequacy Regulation Affect the Monetary Transmission Mechanism?, October 2002

800 Jörg Baten and Andrea Wagner, Autarchy, Market Disintegration, and Health: The Mortality and Nutritional Crisis in Nazi Germany, 1933-1937, October 2002

801 Saku Aura, Uncommitted Couples: Some Efficiency and Policy Implications of Marital Bargaining, October 2002

802 Wolfram F. Richter, Delaying Integration of Immigrant Labor for the Purpose of Taxation, October 2002

803 Gil S. Epstein and Shmuel Nitzan, The Politics of Randomness, October 2002 
804 John Hassler and José V. Rodriguez Mora, Should UI Benefits Really Fall over Time?, October 2002

805 Friedrich Breyer and Stefan Felder, The Dead-anyway Effect Revis(it)ed, October 2002

806 Assar Lindbeck and Solveig Wikström, E-exchange and the Boundary between Households and Organizations, November 2002

807 Dieter Bös, Contests Among Bureaucrats, November 2002

808 Steven Brakman, Harry Garretsen, and Marc Schramm, The Strategic Bombing of German Cities during World War II and its Impact on City Growth, November 2002

809 Florian Englmaier and Achim Wambach, Contracts and Inequity Aversion, November 2002

810 Sarbajit Sengupta, Delegating Recruitment under Asymmetric Information, December 2002

811 Rajshri Jayaraman, On the Partial Public Provision of a Private Good, December 2002

812 Stéphanie Stolz, Banking Supervision in Integrated Financial Markets: Implications for the EU, December 2002

813 Christian Keuschnigg, Taxation of a Venture Capitalist with a Portfolio of Firms, December 2002

814 Inés Macho-Stadler and David Pérez-Castrillo, Settlement in Tax Evasion Prosecution, December 2002

815 Rainer Niemann and Dirk Simons, Costs, Benefits, and Tax-induced Distortions of Stock Option Plans, December 2002

816 Jan-Egbert Sturm and Barry Williams, Deregulation, Entry of Foreign Banks and Bank Efficiency in Australia, December 2002

817 V. Anton Muscatelli, Patrizio Tirelli, and Carmine Trecroci, Monetary and Fiscal Policy Interactions over the Cycle: Some Empirical Evidence, December 2002

818 Claude Hillinger, A General Theory of Price and Quantity Aggregation and Welfare Measurement, December 2002

819 Erkki Koskela and Ronnie Schöb, Optimal Capital Taxation in Economies with Unionised and Competitive Labour Markets, December 2002

820 Sheilagh Ogilvie, Guilds, Efficiency, and Social Capital: Evidence from German ProtoIndustry, December 2002

821 Hans Gersbach and Verena Liessem, Financing Democracy, December 2002 
822 Costas Hadjiyiannis, Panos Hatzipanayotou, and Michael S. Michael, Optimal Tax Policies with Private-Public Clean-Up, Cross-Border Pollution and Capital Mobility, December 2002

823 François Ortalo-Magné and Sven Rady, Homeownership: Low Household Mobility, Volatile Housing Prices, High Income Dispersion, December 2002

824 Syed M. Ahsan and Panagiotis Tsigaris, Measuring the Social Discount Rate under Uncertainty: A Methodology and Application, December 2002

825 Kai A. Konrad, Altruism and Envy in Contests: An Evolutionarily Stable Symbiosis, December 2002

826 Robert S. Chirinko and Huntley Schaller, A Revealed Preference Approach to Understanding Corporate Governance Problems: Evidence from Canada, December 2002

827 Geir B. Asheim, Green National Accounting for Welfare and Sustainability: A Taxonomy of Assumptions and Results, December 2002

828 Andrea Gebauer, Chang Woon Nam, and Rüdiger Parsche, Lessons of the 1999 Abolition of Intra-EU Duty Free Sales for Eastern European EU Candidates, December 2002

829 Giacomo Corneo, Work and Television, December 2002

830 Vivek H. Dehejia and Yiagadeesen Samy, Trade and Labour Standards - Theory, New Empirical Evidence, and Policy Implications, December 2002

831 Geir B. Asheim and Wolfgang Buchholz, A General Approach to Welfare Measurement through National Income Accounting, December 2002

832 Aaron Tornell and Frank Westermann, The Credit Channel in Middle Income Countries, January 2003

833 Gebhard Flaig, Time Series Properties of the German Monthly Production Index, January 2003

834 Campbell Leith and Jim Malley, Estimated Open Economy New Keynesian Phillips Curves for the G7, January 2003

835 Burkhard Heer and Bernd Süssmuth, Inflation and Wealth Distribution, January 2003

836 Erkki Koskela and Leopold von Thadden, Optimal Factor Taxation under Wage Bargaining - A Dynamic Perspective, January 2003

837 Carola Grün and Stephan Klasen, Growth, Income Distribution, and Well-Being: Comparisons across Space and Time, January 2003

838 Robert S. Chirinko and Ulf von Kalckreuth, On the German Monetary Transmission Mechanism: Interest Rate and Credit Channels for Investment Spending, January 2003 
839 Sascha O. Becker, Andrea Ichino, and Giovanni Peri, How Large is the "Brain Drain" from Italy?", January 2003

840 Albert Berry and John Serieux, All About the Giants: Probing the Influences on Growth and Income Inequality at the End of the $20^{\text {th }}$ Century, January 2003

841 Robert Fenge and Martin Werding, Ageing and the Tax Implied in Public Pension Schemes: Simulations for Selected OECD Countries, January 2003

842 Robert Fenge and Martin Werding, Ageing and Fiscal Imbalances Across Generations: Concepts of Measurement, January 2003

843 Giovanni Andrea Cornia, The Impact of Liberalisation and Globalisation on Income Inequality in Developing and Transitional Economies, January 2003

844 Peter Fredriksson and Per Johansson, Program Evaluation and Random Program Starts, January 2003

845 Bernd Hayo and Matthias Wrede, Fiscal Equalisation: Principles and an Application to the European Union, January 2003

846 Syed M. Ahsan and Jaideep Oberoi, Inequality, Well-being and Institutions in Latin America and the Caribbean, January 2003

847 Chang Woon Nam and Doina Maria Radulescu, The Role of Tax Depreciation for Investment Decisions: A Comparison of European Transition Countries, January 2003

848 V. Bhaskar and Steinar Holden, Wage Differentiation via Subsidised General Training, January 2003

849 Paloma Lopez-Garcia, Labour Market Performance and Start-up Costs: OECD Evidence, January 2003

850 Christian Keuschnigg and Soren Bo Nielsen, Public Policy for Start-up Entrepreneurship with Venture Capital and Bank Finance, January 2003

851 Yin-Wong Cheung, Menzie D. Chinn, and Eiji Fujii, China, Hong Kong, and Taiwan: A Quantitative Assessment of Real and Financial Integration, January 2003

852 Gregory D. Hess, The Economic Welfare Cost of Conflict: An Empirical Assessment, February 2003

853 Douglas J. Cumming and Jeffrey G. MacIntosh, Comparative Venture Capital Governance. Private versus Labour Sponsored Venture Capital Funds, February 2003

854 Eckhard Janeba and John Douglas Wilson, Decentralization and International Tax Competition, February 2003 